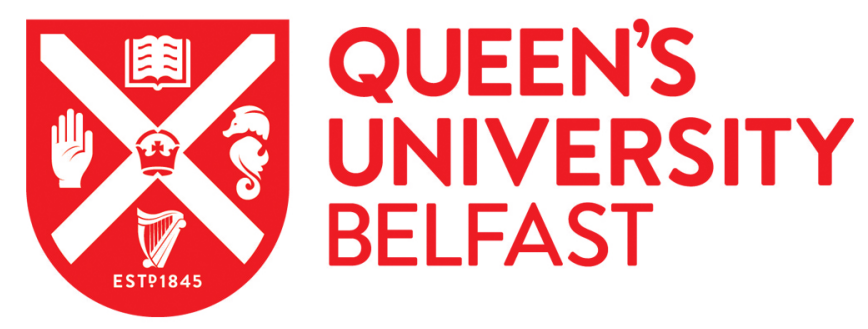

\title{
Imperial straightening devices in disciplinary choices of academic knowledge production
}

Cushing-Leubner, J., Engman, M. M., Ennser-Kananen, J., \& Pettitt, N. (2021). Imperial straightening devices in disciplinary choices of academic knowledge production. Language, Culture and Society.

https://doi.org/10.1075/lcs.21001.cus

\section{Published in:}

Language, Culture and Society

\section{Document Version:}

Peer reviewed version

\section{Queen's University Belfast - Research Portal:}

Link to publication record in Queen's University Belfast Research Portal

\section{Publisher rights}

Copyright 2021, John Benjamins Publishing Company.

This work is made available online in accordance with the publisher's policies. Please refer to any applicable terms of use of the publisher.

\section{General rights}

Copyright for the publications made accessible via the Queen's University Belfast Research Portal is retained by the author(s) and / or other copyright owners and it is a condition of accessing these publications that users recognise and abide by the legal requirements associated with these rights.

Take down policy

The Research Portal is Queen's institutional repository that provides access to Queen's research output. Every effort has been made to ensure that content in the Research Portal does not infringe any person's rights, or applicable UK laws. If you discover content in the Research Portal that you believe breaches copyright or violates any law, please contact openaccess@qub.ac.uk. 


\title{
Imperial straightening devices in disciplinary choices of academic knowledge production
}

Jenna Cushing-Leubner (University of Wisconsin-Whitewater)

Mel M. Engman (Queen's University Belfast)

Johanna Ennser-Kananen (University of Jyväskylä)

Nicole Pettitt (Youngstown State University)

\begin{abstract}
In this piece, the authors question whether critical language research, in its complex collection of researcher choices, is possible beyond the discursive imaginary of critical academic scholarship. In other words, how do (allegedly) anticolonial efforts re-orient towards contribution to the imperial record? We present three vignettes, through which we grapple with the notion that researcher choice exists within the solipsism of academia. In doing so, we frame research and scholarship as a collection of choices, which we believe are better understood as a collection of fraught dilemmas. These dilemmas recognize that all academic scholarship production and its processes are birthed from, and serve, an epistemology of hierarchical social configurations, which serve empire maintenance and expansion. As critical language scholars who bring overlapping and distinct sociopolitical, geographic, and methodological positionalities, these narrative autoethnographic vignettes allow us to begin to see the landscape of researcher choice in the processes and projects of accumulating knowledge production. We identify imperial straightening devices for legitimization into the imperial archive and examine how they work to orient and re-orient critical language scholars towards the ideological and material production of the imperial archive.
\end{abstract}

Keywords: empire, imperial archive, knowledge production, straightening devices, critical language studies

Running Title: Imperial straightening devices 
Can a spider weave its way out of the web that it is being woven into, just as it weaves?

(Angel Lin, 2015)

Just as Lin (2015) questions the possibilities of truly engaging in "a defiant research imagination" within the confines of what is allowable in research itself, we take this opportunity to question whether critical language research, in its complex collection of researcher choices, is possible beyond the discursive imaginary (Rambukwella, 2019) of critical academic scholarship. In just one example of the web, "theoretical vocabulary and discourse" (127) that signal decolonizing or anticolonial thinking and projects act to mask a recursive commitment to colonial control and determination of knowledge. Following Rambukwella's lead, we consider what other mechanisms do this work in the image of critical language studies. In other words, how do (allegedly) anticolonial efforts end up playing the imperial game and reconstituting the imperial record?

We consider researcher choices as expressions of agency through individual actions. Through individual actions (i.e. choices), one's orientations and relationships towards ideologies, processes, and objects are negotiated and operationalized. So, too, are our perceived positionalities at times of reckoning with the ecologies within which we position ourselves and are positioned. We come to the question of choice in academic scholarship and language research as four women scholars and friends who were brought together through academia, dispersed by academia (to labor within academia), and reconvene regularly through mechanisms of academic dissemination (e.g. conferences, which become places to reconnect and touch; practices such as the writing of this manuscript, which become legitimized ways to re-group with each other as intellectually and emotionally stimulated beings, because these practices are in the service of knowledge production and our work).

We live and do language research and scholarship in different locations across Europe and settler colonial contexts: Northern Ireland; Finland; and lands of the Dakota, Hoçak Nation, Potawatomi, Ojibwe, Haudenosaunee Confederacy, Shawnee, Miami, Erie, and Ottawa peoples called Minnesota, Wisconsin, and Ohio in the United States. Each of us approaches our work differently, and in some combination of anticolonial, critical, feminist, and participatory theories and methodologies. Our current constellation reflects academia's projects of claiming territory in its efforts at knowledge production, narrowing, minimization, legitimation, and erasure. These are enacted within what literary scholar Lisa Lowe (2015) explores as "the intimacy of four continents" and critical race and ethnic studies scholar Kit Myers (2014) explores as the intimacy of settler nations. This urges us to better consider "how imperialism has worked in concert with colonialism" (4) in knowledge production, transfer, and removal.

Here, we present a collection of three autoethnographic narrative vignettes (Rådesjö, 2018), through which we grapple with the notion that researcher choice exists within the solipsism of academia. In doing so, we frame research and scholarship as being a collection of choices and fraught dilemmas. As dilemmas, these choices recognize that all academic scholarship production and its processes are birthed from, and serve, an epistemology of hierarchical social configurations (Cusicanqui, 2012/2019; Mignolo, 2009) which serve empire maintenance and expansion. While we were first introduced to this in academia through Mignolo's (2009) writings on zero-point epistemology, as Cusicanqui (2012/2019) describes, these configurations have long 
been clear and taught within and across communities under threat of removal by hegemonic powers, and act to legitimize and subordinate through conceptual and intellectual projects of colonialism (Lowe, 2015; Richards, 1993; Silko, 2006; Wa Thiong'o, 1992). We draw from feminist scholar Sara Ahmed's (2006, 2007b) concept of "straightening devices" to recognize how what we identify to be researcher choices exist within a terrain of options that persistently orient research in critical language studies towards empire entrenchments, white-Euro racial framing, and racial-linguistic capitalism (Cushing-Leubner 2020a, 2020b; Heller \& McElhinny, 2017).

We follow Rambukwella's (2019) challenge of the notion that critical language studies can exist within academia's discursive constructions, and extend this to question its possibilities of existing within academia at all. To illustrate this, we excavate three of our own fraught dilemmas of researcher choice, within each of which lie "the coloniality of knowledge production and the inequalities that stem from it" (Lorente, 2019: 153). As critical language scholars who bring overlapping and distinct sociopolitical, geographic, and methodological positionalities, these vignettes allow us to begin to see the landscape of researcher choice in the processes and projects of knowledge production. Through this landscaping, we identify imperial straightening devices, akin to heteronormative (Ahmed, 2006) and racial (Ahmed, 2007b) straightening devices.

In our vignettes, we identify a complex array of imperial straightening devices across the years of formative socialization into academia. We begin with early socialization into academia through confirmations of disciplinary legitimacy in dissertation work. We then consider viability for retainment to the academy through meeting expectations of tenure and promotion. And we close with excavating processes of conforming to politics of disciplinary novelty in the production of knowledge as situated scholars through selections of appropriate(d) theoretical frameworks and other mechanisms of scholarship production. We identify imperial straightening devices as working to orient and re-orient critical language scholars towards the ideological and material production of the imperial archive (Richards, 1993; Said, 2012).

Regardless of our critical, anticolonial, feminist, and participatory epistemologies and methodologies, we reckon with the impossibilities that are rendered through our straightening by and to academia and the imperial archive, as well as our participations in straightening ourselves and each other towards legitimacy in academia. Through this, we illuminate how imperial straightening devices transmutate efforts against the colonial project into marginalized, unintelligible, extractive, or nullified (i.e. not allowed to exist). We also offer the perspective of imperial straightening devices as a way to shift the concept of choice to one that is in relationship to reckoning and interrupting aspirational desires for contributing to the formation and reconstitution of the colonial archive.

\section{Straightening devices and the Imperial Archive}

\subsection{Imperial Archive}

As language researchers whose work (research, scholarship, and teaching) is funded through our employment with the state and academia, as well as through public-private partnered grants and philanthropic structures, our engagements with knowledge production are in undeniable relationship to the expansion and maintenance of the imperial or colonial archive (Burns, 2010; 
Gopinath, 2018; Lowe, 2007; Said, 2012). Our work is also variably partnered and in relationship with Indigenous, local, displaced, and refugee communities, and it is often in tension with the demands of knowledge production by and for this archive and its purposes. Richards (1993) describes knowledge production by and for the imperial archive as a fantasy of empire made real through the accumulation of knowledge. Richards urges us to understand this fantasy by starting with the colonial project as one of physical and material coercion, violence, erasure, and control. In the fantasy of empire, knowledge production and its ongoing processes and series of constructive choices provide a symbiosis of knowledge and power through the ideological, discursive, and performative. This symbiotic fantasy relies on the academy to continuously construct an archive of the empire to legitimize its power (Lowe, 2015; Said, 2012). Through the imperial archive, academic scholarship production offers an alternative to the reality of brutal biophysical empire expansion through the unifying myth that those within and coercively gathered by empire's hold are instead united by the project of information creation, documentation, tracking, and reification.

\subsection{Straightening Devices}

The fantasy of empire, as Richards (1993) lays out, is that through the choices that constitute the processes of knowledge production, the imperial archive itself serves as a stand-in for the real mechanisms of empire, with its (settler) colonial territorializing and biocultural removal and replacement (Wa Thiong'o, 1992; Wolfe, 2006). Thus, the imperial archive is a site of knowledge production, 'reading' it [is] a technology for administering and knowing the colonized population that both attests to its own contradictions and yields its own critique. In this sense, the [colonial archive] is not a static comprehensive collection of given facts but a living record of the methods for administering the colonies. (Lowe, 2015: 126)

What, then, feeds this living record, despite the belief of critical and anticolonial scholarship that may position itself as antithetical to the maintenance of the colonial project? Here, we have found Sara Ahmed's (2006) concept of straightening devices to be a clarifying gift. Birthed in critical queer studies, Ahmed describes straightening devices as how we are kept in line through corrections and repetitions that follow a normalized canon and recursively construct a predetermined legitimacy (562). As Gopinath (2018) provides, these straightening devices discipline our material selves and our "desires into a singular, intelligible, normative mode of being" (75), thereby defining the process of constructing an academic discipline and maintaining the boundaries of those disciplines. Recalling the words of one of Jenna's early mentors: "The point of disciplines is to discipline you."

We extend Gopinath (2018) to consider how disciplinary straightening devices are used (and taken up) to straighten scholarship that may move outside of or against the imperial archive in ways that re-shape resistive, fugitive, and sovereign scholarship as intelligible to the academy (and thus the archive and its singular aims). This straightening reconstitutes normative modes of being language researchers and scholars, as is determined by what is legitimate and beneficial to the security and maintenance of the empire's control of legitimized knowledge, and therefore legitimized to control peoples and lands and their relations. These straightening devices have been explored extensively in Queer studies, and to a lesser extent in connection to white racial phenomenology (Ahmed 2007a, 2007b). In the following vignettes, we consider straightening 
devices in connection to the myth of epistemological choices within the work of language scholarship production done in relationship to the academy, and therefore done with some relationship to being logged into the imperial or colonial archive.

\section{Autoethnographic narrative vignettes}

As women-scholar-friends, we have known each other for over a decade at the time of writing this manuscript. We came to know each other as friends and as graduate students in different cohorts of the same $\mathrm{PhD}$ program. As we moved deeper into academia in varying directions, our friendship ties have been stretched geographically and emotionally, placing us always in intense distance relationships with women we came to know, love, and thrive with intellectually. The notion of our collective relationship to each other and our intellectual work has tied us with rubber band-like strings, as we pull apart geographically, epistemologically, and methodologically - yet remain connected.

Considering this, we drew from collective methodologies that legitimize the knowledge kept in shared and resonating memories, which place people and experiences in relationship to systems and colonial enterprises (e.g. Nagar, 2014). Over eighteen months, thousands of miles, internet networks, and early circulations of the COVID-19 global pandemic, we first used collective memory sharing, and then collaborative autoethnography (Chang, Ngunjiri, \& Hernandez, 2016) to do collective and collaborative self-interrogations, with the aim of making invisibilized mechanisms of epistemological violence visible (Smith, 2015).

As a form of autoethnographic method, we combined narrative vignettes with critical reflections (Rådesjö, 2018). Autoethnographic narrative vignettes seek phenomenological expressions and take many shapes, including poetic narratives (Garbisch, 2012; Hanauer, 2012; Moustakas, 1994; Saldaña, 2021; Verene, 1999). We chose to extend the form of autoethnographic narrative vignettes used by Rådesjö (2018), in the hopes of preserving the narratives of lived experiences offered in the sharing of memories while extending the analysis of phenomenology through collaborative critical reflections. We came to these critical reflections through a process of repeated oral analysis, followed by shared writing and the use of critical asynchronous annotations on shared writing documents. After bringing an initial version of this manuscript to review, the reviewers and journal editors became part of our collective analysis, with their comments and insights becoming part of the asynchronous reconstitution of what could be made visible through the memory narratives.

\section{Autoethnographic narrative vignettes of researcher choices}

We share three autoethnographic narrative vignettes that take into consideration examples of researcher choices from critical language scholars who each locate their work as epistemologically and methodologically situated within anticolonial, critical race, and/or feminist research paradigms. While these vignettes can be read individually or shuffled into any order, we arranged them to reflect processes of imperial straightening across the early lifespan of socialization into academia. They reflect straightening at the stages (1) formation of research and scholarship trajectories (i.e. academic "training" through dissertation), (2) movement through the 
probationary threshold (i.e. tenure and promotion), and (3) claiming relevance in the field (i.e. sustaining research and scholarship trajectories). With each vignette, we share the imperial straightening devices we have come to identify, then the memory vignette, followed by our collective critical reflection. We do this in the hopes that readers might participate in their own heteroglossic reading of these memories and analysis - perhaps in recognition, perhaps in critique, but we hope not in silence.

The purpose of these vignettes is not to delineate the full range of imperial straightening devices, nor is it to identify new sites of struggle within academic work. Rather, their purpose is to deneutralize the processes of finding, producing, and sharing knowledge (Lorente, 2019). In so doing, excavating these examples uncovers discursive and structural injustices that imperial straightening devices enable and represent through the narrowing, widening, or feigning of a researcher's choice. Through them, we try to show how individual scholars' choices - including the believed absence or illusion of them - interact with varying disciplinary and academic straightening devices under specific conditions. This interplay can re-orient epistemic and epistemological processes rooted in resistance, hope, and re-imagination towards reinstantiations of the imperial archive.

\subsection{Mel: Academic "training” in (mis)recognition and knowledge production}

Straightening devices: Dissertation-as-product, training-as-expertise, academic disciplines-assilos (e.g., applied linguistics), language-as-object, counting/categorizing-as-neutral, time/deadlines, identity politics

As a white settler woman conducting research with Indigenous language teachers in Indigenous spaces, I know better than to trust my perceptions as reflections of an objective reality. I extend this distrust to institutions of schooling and the academy, yet since my early years in higher education, these same institutions have held (and continue to hold) me in matrices of complicit positioning and production.

Memory Narrative: In spring of 2016, I was collecting ethnographic data in an Indigenous language classroom to better understand the work of bilingual language teachers who are still learning their Indigenous ancestral language as they teach it. Though this was my first time conducting research in the field, I had been doing Indigenous language revitalization work (mostly non-academic) with teachers and Elders for the past several years and was learning the language; and I regularly engaged with my positionality, my potential to do harm, and the likelihood that I would encounter phenomena unknowable to me while collecting data at study site. In hindsight, I was also secure in the belief that my training in applied linguistics and education had prepared me to do research that would contribute to the field and support the educational goals of the participating teacher and school.

Early in the data collection, I realized that my focal participant (i.e., the teacher-learner) was not relying on the practices that language education literature recognized as "good language teaching." There seemed to be too much scripting, too much teacher talk, too much English for the teaching to be recognizably "transformative" based on my understanding of the literature. This realization was a critical point of reckoning, though I struggled to articulate how and why 
at the time. I feared that a transparent rendering of the teacher's practice relative to how I understood critical language pedagogies, would misrepresent the teacher as unskilled. This would be false and would do violence. Important things were happening in that classroom, but my reliance on existing applied linguistics literature to characterise them left me with an inadequate grammar for analysis and representation. The focus on language as an object or skill obscured and flattened the overall extra-linguistic effects of being a part of that classroom.

I perceived the situation as having two options: (a) proceed as planned (and betray my colleague), or (b) abandon the dissertation altogether.

These stark, binary choices were not officially presented to me by any person or institution. They emerged from how I understood my positionality (e.g., my identities, commitments, obligations, investments, desires) and associated expectations in higher education, academia, and Indigenous spaces. My insistence on framing this study as an examination of transformative classroom language practices was still predicated on a colonial desire to categorize and record according to existing archival models, contributing to the fiction of a possible "comprehensive" (Richards, 1993: 7) knowledge of critical language studies. My understanding of what was recognizable as transformative was informed by literature examining a variety of learning contexts (admittedly few Indigenous ones). When I presented my perceived dilemma to colleagues I was advised to "count" things (see the analytic memo in Figure 1) as a way to represent classroom practices without doing harm.

\begin{tabular}{|c|}
\hline Memo ID info \\
\hline $\begin{array}{l}\text { Nov. } 1,2016 \\
\text { Transcription of } 5.3\end{array}$ \\
\hline Puzzle/data \\
\hline $\begin{array}{l}\text { As I transcribe the interactional data in small groups, I'm wondering about how to } \\
\text { code. }\end{array}$ \\
\hline $\begin{array}{l}\text { S---- suggests I count things as a sort of straight-empirical approach to what I'm seeing } \\
\text { and while initially I was thinking I should just count Ojibwe vs. English utterances, } \\
\text { that's actually really complicated and ambiguous in a lot of situations. }\end{array}$ \\
\hline $\begin{array}{l}\text { I'm watching the video where H------ writes words for the Cinco de Mayo acrostic } \\
\text { activity and for M she wrote M------- and for A she wrote A------- and for Y she wrote } \\
\text { her own name backwards (-------H). }\end{array}$ \\
\hline $\begin{array}{l}\text { This is an example of playfulness and relating to her classmates and to herself. Both } \\
\text { awesome. }\end{array}$ \\
\hline $\begin{array}{l}\text { Maybe I could code for general behavioral patterns like: (1) follow instructions, (2) } \\
\text { follow instructions playfully, (3) don't follow instructions playfully, (4) resist } \\
\text { unplayfully }\end{array}$ \\
\hline Or code for participant structures like S-S, S-T, or something like that. \\
\hline
\end{tabular}

Figure 1: Analytic Memo on 'counting things' 
My hope that a "straight-empirical approach" (my words at the time, and before connecting this with the idea of straightening devices) might allow me to continue with the dissertation while avoiding a negative portrayal of classroom practice reveals my orientation to the project as primarily based on existing models for research within the imperial archive. It shows how the dissertation-as-product functions as a straightening device--prioritizing task completion over all else, as if countable codes are less capable of symbolic violence or somehow less a settler colonial technology (la paperson, 2017) than other forms of analysis. Unsurprisingly, this approach did not provide me with a more favorable or honest picture of what was happening in that classroom and failed to reveal any hidden recognizably transformative pedagogy.

Ultimately, I continued to learn from my colleague and from her practice, as she helped her young bilingual students to develop in significant (extra-linguistic) ways (e.g., through observation, collaboration, consensus building, experience, story). My over reliance on the existing archive and its instruments had oriented my original view of the classroom in such a way as to obscure my view of the teacher's expertise. I thought language revitalization was aided by fluency in structural linguistic concepts, when, in fact, this language-as-object orientation prevented me from seeing how this skilled teacher facilitated a plurilingual classroom atmosphere that resembled extended family structures (building on existing relations among some of the young people and adults in the room). There was intimacy and trust, and identities were allowed to be dynamic, fluid, and emergent as academic content mixed with talk of Fortnite strategy and snaring rabbits. Some ways of being bilingual at school were not recognisable to my settler experiences nor to the settler colonial archive on which I was relying to generate new knowledge about language learning and use.

Thanks to continued conversations with colleagues, supervisors, friends, and literature from outside the discipline, the dissertation objective changed to focus on the social relationships in the classroom and the ethical project of reclamation (rather than language instruction). I learned a great deal about disciplinary discourse and Indigenous language, leaving me with numerous unresolved tensions that I still feel with the field of language education.

Critical Analysis: This vignette's characterisation of perceived choices highlights the numerous assumptions and straightening devices embedded in Mel's participation in the colonial archive project. Years of experience with Indigenous community activists had taught her distrust in colonial institutions, yet when it came to the work of the dissertation, she chose to rely on institutionalised practices and resources, and to conform to the representational norms of academic research - necessities for the terminal degree she desired. Ahmed (2006) notes that "it is not that the object causes desire but in desiring certain objects, other things follow, given how the social is already arranged" (563). Though Ahmed is referring to desire in terms of bodies and "orientation" in this quote, it helps here to explain the various straightening devices at play and the ease with which they were introduced into Mel's sense-making of her dissertation.

The dissertation represents Mel's desire to participate in knowledge building about Indigenous language learning and, ironically, alternatives to colonial pedagogical practices. Along with this desire comes a need for passing institutional assessments, for conforming to genre-specific conventions and timelines, and for producing something that is recognisable and original. In these efforts, analytical and representational dilemmas arose as "other things" that follow in the 
existing arrangement of academic straightening devices. Importantly, the straightening devices that were most salient to Mel in the moment (i.e., dissertation conventions, recognisably innovative classroom practices) are only a partial picture of the ways in which the tendency "toward straight objects" (Ahmed, 2006: 557) were enacted in this vignette. Certain fundamentals of knowledge generation (e.g., what constitutes data, how is knowledge recognised and represented, whose interests are served) were assumed to be ethical and free from any "obfuscating discourses" (Cusicanqui, 2012: 115) that reproduce coloniality and domination.

The straightening devices of the academy are not equally visible, and this (in)visibility is significant to how and when Mel conceived of herself as an agentic actor with the possibility of choice. At the initial challenge point of the vignette, when Mel felt unable to report data that reflected negatively on her friend and colleague, tension and choice arose from dissertation as a straightening device that not only limited her choices to a binary of "stop/go" but also constrained her ability to reframe the study into a new albeit less familiar form. For instance, when Mel did not see the kinds of transformative classroom practices she had hoped to find based on her reading of literature in applied linguistics and Indigenous language revitalization, she perceived it as a problem of identity and relationships rather than as an opportunity to learn more about the complex ideological and experiential intersections that informed her practice. ${ }^{i} \mathrm{Up}$ to this point, Mel's orientations to Indigenous language education had been informed by her role as a language activist ally and learner - kept separate from research. In these settings she played a supportive role, responding to needs and desires as they emerged, and deferring to Indigenous colleagues in decision-making. As an outsider settler, she had less community knowledge and she was differently invested in the work, an orientation reflected in Mel's more tentative allyship in which she tended to resign her privilege rather than operationalize it (Accomplices not allies, 2015). The worries that grew from her first attempt to do research in an Indigenous language context point to the ways in which the work of the colonial archive shifted/straightened her perceptions of human relations and responsibility.

Later, when she pushed back on the presumed utility of counting and categorising, Mel made a choice to produce research that demonstrated her teaching colleague's strengths. This choice pulled her away from her coursework in applied linguistics and her preliminary exams straightening devices in the academy that orient to discrete structures and hierarchy. She was able to make the study recognizable as a dissertation to her committee by relying on alternative, relational conceptions of language and genre conventions and literature from outside the discipline (but elsewhere within the archive, including committee members themselves). Importantly, we do not present this choice as a complete rejection in full agency and rebellion against the colonial archive. Rather, it is a reflection of the deceptively broad range of movement within academic practices. Mel's choices were shaped by commitments to human relationships and ethics concomitant with academic processes. She was only able to recognise and articulate these multiple orientations fluently enough to arrive at a challenge point because of the critical reading and relationships she had encountered through engagements with certain aspects of the academy (e.g., decolonizing literature, brilliant friends, activist colleagues).

These academy-mediated encounters with people and ideas from both inside and outside the work of the archive can shift orientation like straightening devices can, though the straightening effect of each may orient her to choices differently. Recognition of the potential for her research 
to do harm may not have been visible from other, more vertical angles, though the limited choices that she perceived as available to her in the moment reflect how closely her angle of orientation was still aligned with the aims of the colonial archive. Similarly, Mel's ambivalence around the suggestion to look for recognizable structural (countable) phenomena (i.e., an ontological shift in grain-size, not necessarily a shift from qualitative to quantitative methods) was perhaps only recognisable as a choice because of the existence of alternative, softer angle that still oriented Mel closest to the aims of the archive. Gramsci (1999) describes hegemony's power as partial rather than one of total domination. The imperial colonial archive is an extension of this hegemony and thus, is caught up in the "unstable equilibrium" that it maintains. This instability may allow or even require occasional adjustments. In what ways then, might the myth of choice cloud our view, perceiving alternative angles as subversive rather than still in the service of the archive?

\subsection{Nicole: Viability for tenure and promotion in engaging in critical reflexivity}

Straightening devices: Disciplinary-viability, legitimacy-to-the-archive, tenure-as-archivalpresence, equivocation-of-epistemic-refusals, language-as-object, time/deadlines, identity politics, review-as-archival-appeasement, invisibility-of-disability

As a white, highly-educated, middle-age, middle-class woman from a large metropolitan area, I struggled to make sense of some pedagogical dilemmas I encountered teaching at a mid-size public university in Youngstown, Ohio, a small, deindustrialized city with a racially diverse population. Youngstown continues to hold to "steadfastly separate ethnic cultures" (Linkon \& Mullen, 1995: 27), with continued race-based segregation in housing, education, and workplaces. In recent decades, the metro area has been grappling with the effects of over 40 years of outmigration due to deindustrialization, and slowly working to rebuild a socioeconomic identity that is rooted in a post-industrial image, removed from the settler colonial processes of land territorialization and extraction, and the destructions of late capitalism.

Memory Narrative: In early 2020, I submitted a paper for anonymous peer review to a special issue of an English Language Teaching (ELT)-focused journal. In it, I delineated some pedagogical dilemmas I encountered teaching in the ELT licensure program, specifically related to teacher candidates working towards licensure in areas other than ELT, but who were required to take courses on teaching emergent bilingual students. Despite the racial makeup of Youngstown, and in line with the racial makeup of U.S. teachers, nearly all of the students/future teachers were white. None of them identified as Native or Indigenous to the lands where Youngstown was built. I constructed this paper around discussions of social justice and English language teaching, and I shared how some of these teacher candidates appeared to resist taking on identities of ELT professionals, as well as the anti-bias and multilingual pedagogies promoted in the professional standards that guide the courses' curricula. I then wondered how I, as course designer and instructor, contributed to creating, shaping, and directing this resistance and, in my initial paper draft, I wrote:

Drawing on Siefert, Salas, and D'Amico (2018), I began asking: What 'colonizing assumptions' (399) do I bring to my work as an ELT teacher educator in Youngstown? In what ways do I convey that teacher candidates here need to be 'fixed' to be better teachers of emergent bilingual 
students? What local knowledges do I fail to acknowledge? A reviewer encouraged me to rethink my use of the term "colonizing assumptions" "if the racial and historical dynamics of colonial contexts" did not apply, and I wondered in what ways my choice to include Siefert, Salas, and D'Amico's (2018) term “colonizing”" was aesthetic. I understand myself as a white settler bound up in webs of white settler colonialism - resisting, participating in, and perpetuating them as I move about the world and especially as I teach. A clearer understanding of these positionalities would be salient to my students as future teachers as well. Excavating the thinking, history, and gaps in my knowledge that informed my choice to use "colonizing" from the quote would have been worthwhile not only for the manuscript at hand, but for my scholarship overall and work with future teachers. However, I felt time was scarce. I had recently received counsel from a more senior scholar to lean into the pragmatics of academic production in order to be better positioned for tenure/promotion, which rests heavily on the number of publications on your vitae and the prestige of publication outlets in your disciplinary field. As a publication in a special issue of a high profile journal that was one of the official publication outlets for the discipline, acceptance meant increased viability to my field, my institution, and the stability of my positions within them. I had nearly withdrawn the paper a few weeks earlier as I attempted to re-balance workload and health concerns during the early days of COVID-19, and I felt I needed to use the limited time I had for revisions to address what I decided were more substantial paper revisions. I viewed the reviewer comment as discursive: critiquing the use of a modifier ("colonizing" assumptions). I decided that reflection on one word in a piece would not receive my attention, especially as my bid for tenure and promotion was imminent. I removed the term colonizing from the paper, and retained assumptions: "What assumptions do I bring...?"

Critical Analysis: At the time, Nicole described this revision as minor: One word occupies little space in a paper, and the choice to remove the word required little explanation to editors and reviewers, especially as the choice was oriented to a reviewer's recommendation. Today, she views the choice to omit the term colonizing as located within entanglements of pressures to produce for the imperial archive on specific timelines, which de facto demand certain forms of able-bodiedness from producers, as well as access to certain kinds of social networks and resources.

Despite a desire and responsibility to engage the necessary reflexive study into the dialectic intersections of colonialism, racialization, and place specific to her work in this context, the need to do so on a specific timeline for publishing and tenure was not in line with either the paradigmatic depth of the question or the way that time function for Nicole as a person inhabiting a body with disabilities. Here, we consider how disability is a sociopolitical space that can be entered into at any point in life, including quite suddenly after being socialized in not navigating disabling contexts. Additionally, invisible disabilities and the pressures to keep them invisible both to ourselves and to others means that the pathologizing of "failure" in place of the recognition of disability is pressed on many as a straightening device in itself. For Nicole, her own learning to navigate disability involved difficulty ascertaining the shift in time that is needed to engage with and complete tasks. This intersection of the physiological, cognitive, and emotional included a rupture in being able to interpret and embrace the signals her spine gives her regarding its own limits, e.g, "If I don't stop computer work soon, I won't be able to carry out activities of daily living, such as cooking, laundry, or taking out the trash, for several days or weeks." 
For Nicole, living with physical and invisible disabilities is directly counterbalanced by neoliberal constructs of self-reliance (Russell, 2019). Disability flexes her towards interdependence. Quite literally: she asks for help from others, in order to redistribute her physical, cognitive, and emotional loads. However, she made these paper revisions in the early months of COVID, living alone and far from family, which made finding help difficult. She felt particularly physically vulnerable during those months, and prioritized keeping her body physically healthy enough to perform daily life tasks so that she would not need assistance from others until COVID restrictions were eased or lifted. She learned that two keys for accomplishing this were pacing her work and taking on less than she had been socialized to take on as a person who had long fit into abilising systems. Ahmed (2006) writes, "We can recall here the different meanings of the word pressure: the social pressure to follow a certain course, to live a certain kind of life, and even to reproduce that life, can feel like a physical press on the surface of the body, which creates its own impressions for sure" (549). The pressure to contribute to the imperial archive - which opens the doors of tenure, sealing Nicole's legitimacy in the academy wielded a literal "physical press on the surface of [her] body" (555), demanding that the bones of her spine straighten (impossibly) to function in ways that allow her to produce on specific timelines, already incongruent to meaningful study.

Although the removal of the term colonizing may not have influenced the fate of the paper, the delimitation of time-intensive study in favor of the quickness of following the lines of erasure reflects the tendril growth of empire in archival entries. Indeed, Nicole's choice existed mostly outside of the term itself, leading a co-author to ask, "What does it say about the imperial archive that this phrasing (i.e., removing colonizing) can be framed as peripheral/optional to the project of documenting and generating knowledge?" Ahmed (2006) writes, "Following lines also involves forms of social investment. Such investments promise return (if we follow this line, then this or that will follow), which might sustain the very will to keep going" (555). And so it is when we do not follow lines - when we let go or drop or erase in order to maintain production, all of which sustain the tacit holds of empire.

The paper in Nicole's vignette not only constituted part of her sense-making surrounding the ways that Youngstown's histories and narratives shape local identities, but also an entry in the imperial archive, necessary for her upcoming bid for tenure and promotion. In many U.S. colleges and universities, tenure and promotion confirm one's scholarly and personal value to the academy and the institutional body. In literal ways, it allows them to keep their job, thus remaining a producer of legitimized imperial knowledge and an archival gatekeeper and archivist. Her physical relationship to the academy reflected a common demand for scholars to sacrifice the personal and ties to home, land, and their own local in order to claim place in the academy. The demands on early scholars to cut ties with their own locals to prove commitment to the academy can be seen in far-flung moves to enter graduate school and its socialization and education into their roles as archival producers, gatekeepers, and archivists. And it can be seen in the demands to move across countries and oceans for employment and for knowledge production and dissemination (e.g. research sites and conferences). In the case of Nicole, she had been positioned to "choose" to break ties with her personal and local in order to remain in academia twice within six years, moving nearly 1,000 miles $(1,600 \mathrm{~km})$ each time. In her pre-tenured positionality, these choices took place within a sustained precarity within the academy requiring scholars to alienate from the local, and the social relationships that support their 
physical well-being - to prove their commitment to the academy. This alienation from the local makes sense to the academy in relationship with its preference for scholarship that engages the epistemic violence of a disembodied zero-point epistemology (Castro-Gómez, 2007).

Promotion and tenure offer fertile ground for the use and success of disciplinary straightening devices, because it plays off of multiple precarities: personal, material, professional, intellectual, social, and physical. The promise of promotion and tenure is securing your role in the project of empire (and thus the imaginary of certain types of individual safety, despite its violences; e.g., tenure and promotion augment economic safety, while demanding physical sacrifice). The threat of promotion and tenure is that the measure of your value of existence (the degree to which you strengthen the archive's legitimacy) will be determined as worthless by a cadre of disembodied gatekeepers (i.e. a core group of trained academic colleagues, academic peers, academic administrators). Constituent to this threat is that, once deemed worthless to the legitimization of imperial power, you will be removed from the archive, nullified to the academy, and - having severed ties with the humanizing world - cease to exist. For some scholars, within this state of disorientation, the myth of one's precarity - the myth that one would actually cease to matter or exist - amplifies the will to choose to comply with being straightened to our disciplines and, by extension, amplifies the desire to "straighten" our bodies into certain kinds of ablebodiedness in order to comply with such disciplinary straightenings.

The analysis of Nicole's paper revolved around whiteness and working-class identities, not because she is a critical race or class scholar, but because they pervade local discourse in the new local and at her university. Before being offered a job at this institution (primarily due to her positionality within racial and class formation hegemonies), her orientations had not been towards critical white racial formation nor studies in social class. However, her current location within the academy was a site for extraction and production specifically related to the white working class, so that scholarship which examines white working-class experiences is highly valued. This scholarship continues colonial projects of local extraction, by creating scholarly products that are either physically inaccessible or linguistically unintelligible to the local population they purport to reflect, while simultaneously sustaining the erasure of Indigenous peoples. The accumulation of knowledge connected to this discrete topic benefits the prestige and presence of a focal-archive (i.e. a particular accumulation within the larger imperial archive), and is therefore contributing to the focal archive adds additional promise to her continued existence in the academy (i.e., to the individuals and groups charged with approving or denying her case for tenure and promotion). In this context, knowledge production reflected a reorientation, which she was rewarded for actively producing archivable knowledge in relationship to, even as she came into relationship with their horizons. From Nicole's orientation of desire for archival approval, these constructed "the conditions of possibility that shaped what could be written...what competencies were rewarded in archival writing, what stories could be told, and what could not be said" (Stoler, 2002: 91). And part of what could not be said was the settler colonial reality of the local where she was producing knowledge about the production of settler colonial educators. For Nicole - and many authors of the colonial archive - construction of acolonial stories of settler colonial reality can be argued as legitimate, and settler colonial realities as impossible to tell because they have been absented from the archive (O'Brien, 2010). What is made possible by this is the continued reconfiguration of an acolonial "social justice" or the myth that justice exists without decolonizing (Tuck \& Yang, 2018) through an ethic and 
practice of rematriation (Tuck, 2011) and Land Back (Pieratos, Manning \& Tilson, 2021). Nicole's vignette demonstrates the power of the imperial archive to shape perceptions of choice and how we see our own subjectivities relative to the archive's project of recording the world in order to control it. Nicole describes a disembodied interaction with a reviewer, that is, a gatekeeper of the archive, which many of us reading have certainly been or are or will be. Gatekeeper (reviewer) interactions map a collection of choices and complex determinations of meaning, worthiness, engagement, and refusal. In this example, Nicole describes a choice to revise as a choice to determine what is worthy of further reflection in light of pressures to maintain physical health - which also reveals how choices can morph, be obscured, be made visible, and be physically felt in the body. In these situations, what and who is doing the straightening? Is it the reviewer-scholar-gatekeeper's imposition of their/our perceptions and meanings, the author-scholar-contributor's intentions, perceptions, and choices, the editorscholar-archivist's determinations of what will be most beneficial and appropriate for the archive? Nicole describes a choice in which her agency felt limited, regardless of whether or not it was. In this way, imperial straightening devices offer disciplinary comfort to critical - but not decolonizing - scholars' aspirations of contribution and acceptance to the archive. Even when choices do not seem as if they are ours to make with much agency, it reflects how the aspiration for inclusion in the imperial archive influences how we may choose to work for and against it.

\subsection{Hanna: Chasing after novelty and disciplinary criticality in choosing a theoretical framework}

Straightening devices: novelty, publication as legitimation, disinvestment (from work towards equity) and distraction (from complicity), collaboration under the auspices of empire

Hanna offers incidents that have complicated her choice of theoretical frameworks for a book she co-edited and a paper she co-authored within that book. Her position as white European settler who works in and for the academy allows her to engage in processes of writing and editing for publication in ways that are normalized and appear innocent to many in the context of the predominantly white institution (PWI) where she works. As her vignette illustrates, comments from colleagues can break through this normalization and trigger questions such as 'What is novel?' and 'What is critical scholarship?' (Ahmed, 2017; McElhinny, 2019).

Memory Narrative: In recent years, I have been involved in co-editing a collection of chapters that examine different aspects of language education through a framework of New Materialism. This volume is one capstone product of a profiling initiative (Virtanen, Silander, \& Pietilä, 2014) which was funded by the Academy of Finland (2016-2020) with the goal of establishing and developing the field of applied language studies at my university. The volume includes a chapter on language-based school choice I co-authored with two colleagues from Mozambique and Finland. We analyzed data (focus groups, interviews, and policy documents) from both contexts to better understand parents' choice of opting their children into or out of language-focused programs, i.e. bilingual education in Mozambique and "world language" courses in Finland. In compliance with the new materialist framework of the volume, we used the concepts of smooth and striated spaces (Deleuze \& Guattari, 1987) to guide our inquiry and writing. Deleuze and Guattari make a distinction between smooth spaces, such as oceans, that allow multidirectional movement, and striated ones, such as cities, that direct and restrict movement. They emphasize 
that smoothness and striation always occur in hybridity. In our chapter, we used the framework both literally (e.g., for ways to school) and metaphorically (e.g., for access to resources or information) to examine choices parents make for their children's education. As the person among the author group who did not have any data to contribute, I volunteered to take the lead on the theoretical framing, as well as some data analysis and conclusions that would tie our analyses together. Among the feedback I received on both the volume and the chapter, two points stand out to me as particularly persistent: First, as editors, we were repeatedly confronted with the question "What is new about this?" - "this" usually referring to our choice of New Materialism as theoretical framing. The persistence of this question led us to organize most of our introductory chapter around responses to it. Second, questions about our critical approach, i.e. our (not wholly successful) attempts to leverage New Materialism for social justice-oriented approaches to language education research, followed us throughout the process. These included comments about the framework being ideologically biased and moralistic due to its critical approach, but also feedback on inconsistencies in our criticality. For example, when I presented the co-authored chapter-in-progress at a conference on behalf of the author team, one white European senior colleague asked me why I had chosen a "white framework" for our data from Black African communities. Not knowing how to respond, I admitted to needing time to consider their question. In reflecting on my inability to respond to this question, I considered my own positionality in the author team, at my institution, in the academy, and in society at large. As it lays out how straightening devices operate within these contexts and shape my choices, this paper is part of my ongoing considerations. Despite the understandings I gained from my engagement in the writing process and the conversations accompanying it, the coloniality of knowledge production cannot be resolved - certainly not by another contribution to the imperial archive.

Critical Analysis: "What is new about this?" is a common question of gatekeeping in the academy. The gates of the colonial archive open only to those who produce what is recognized as novelty. Such novelty exists on a fine line of being similar enough to archived knowledges in order to be recognized, and different enough to be considered worthy of archiving. In theories commonly subsumed as New Materialism, Hanna saw the potential to find this delicate balance. Or rather, she was able to imagine ways in which she as white European settler could successfully present scholarship within New Materialism as novel to those who are like her, i.e. the (other) gatekeepers of the archive. As editor of a book, her task was not mainly to discover and present something truly novel (if this were even a possibility), but to discursively construct novelty around an idea in a way that would be understandable and acceptable to the (fellow)keepers of the imperial archive. Such (re)quests for novelty in the academy have contributed to processes of epistemic violence and injustice. In an attempt to construct something as "new" and thus legitimize their work as novel or original, academics may feel compelled to create the illusion of an epistemic terra nullius as a building ground for their knowledge colony. Epistemic violence can be understood as an arm of the imperial archive that complements the colonization of land, for instance that of the Gĩkũyũ in Kenya as described by la paperson: "There, lands of Indigenous Africans were declared terra nullius, making way for white land titles, and as the land was bought and sold under their homes and under their feet, the Gîkũyũ became tenants on their own land" (2). As editors of a volume, Hanna and her colleague were continuously probed to identify their epistemic "terra nullius": What was the knowledge gap, the empty, uncharted land that they wanted to settle on, both in terms of what they were studying and how we wanted to go 
about it? The choice of theoretical framework of both editors and authors can be understood as an attempt to legitimize their work as first settlers on uninhabited epistemic land.

Can novelty mean hope? Maybe the quest for novelty does not have to supplant existing knowledges and can instead crack open spaces for scholars to participate in the academy in ways that sabotage the imperial archive. If, with la paperson, we believe that desires and efforts to decolonize the academy can and do exist, novelty can be the invitation for something "wonky" in Ahmed's (2006, see below) sense to enter, a possibility for rebuilding imperial technologies to work against themselves. la paperson uses scyborg "to name the structural agency of persons who have picked up colonial technologies and reassembled them to decolonizing purposes ... [s]cyborg is system-interference and system-witchcraft, the ghost in the machine" (la paperson, 2017: xiv). Something new could be something scyborg that reworks the technologies of the imperial archive and throws a wrench in the wheels of the academy, while necessarily remaining within and complicit in the project of the imperial archive.

The striving for novelty can imbue all research activities. The research questions in the chapter asked how parental school/program choice interacted with smooth and striated socio- material realities and what role language played in this process (Ennser-Kananen et al., under review). Tying themselves to the theoretical framework through the research questions clarified that the chapter was motivated not merely by empirical but theoretical curiosity - in other words, the goal was (also) to try out a new materialist framework and see what it might do, to test if it was "the right kind of novel". Thus, Hanna's choice did not follow logically from an empirical gap or research objective, nor was it separate from her aspirations, positionality, and socio- historical location. Rather, the process of choosing a smoothness-and-striation lens was pervaded by naive playfulness, the aspiration to gain footing in an academic institution and in the academy in general, and by a wish to respond to continuous requests for novelty.

In reaching for the "right kind of novelty" that the academy would approve of, Hanna's desires as editor were straightened towards the goals of empire; and as she became invested in the process of disciplining herself and others to find and walk that fine line, she became disinvested in the socio-political commitment of her work (see Rambukwella, 2019). Imperial straightening is an absorbing process that encroaches on everything else, and on everyone else.

Not only did Hanna invest in the straightening process through searching for novelty, she also carried it forward by reaffirming and demanding the same criteria for novelty from the contributors to the volume, thus ensuring that the mills of empire continue to grind. As Ahmed (2006) said, "[1]ines are both created by being followed and are followed by being created" (555). A lot of work that enables the quest for novelty imaginaries goes unnoticed. For instance, Hanna's ploughing through new and dense literature during the summer months came at the expense of family time and recovery. Her choice to invest in learning a "novel" framework took a toll on personal and professional wellbeing of many people - work that relegates to the background, like the cleaning of Husserl's writing table, which remains unseen but critical to the philosopher's work (Ahmed, 2006). This invisible labor exists so that the straightening towards "novel" imperial knowledge production can progress without obstruction under the veil of academics' personal choice. Making such work visible is unconventional, to say the least. 
In the process of writing and presenting the paper and editing the book, straightening devices surfaced that aimed to bend Hanna's work towards particular ways of enacting disciplinary criticality. On the one hand, the message Hanna received was that criticality, for example the affiliation with scholarship that is invested in working towards social justice, needed to steer clear of moralistic undertones, and instead offer a voluntary scholarly avenue, rather than demanding commitment. On the other hand, criticality was described as practice that takes racializations of communities and theories into consideration and acts based on these "color lines". In addition to these different demands of criticality, Hanna was also looking to satisfy the demands of the academy enough to remain a legitimate and recognized part of it. As a result of negotiating and balancing these different expectations, Hanna ended up performing a discursive imaginary of criticality (Rambukwella, 2019) that was socio-politically toothless.

When straightening devices bent Hanna's work towards serving colonial processes, they also acted as distraction from her colonial complicitness, which was, for instance, reinforced by her and her co-authors ignorance of Indigenous scholarship's resistance to materialities and materialism as a means of codifying social-material relations (Tallbear, 2017). Rosiek, Snyder, and Pratt (2020) identify this ignorance as a willful reluctance and a choice of the academy not to engage with Indigenous theory, since "choices are being made about which literatures are worth the effort of engaging (3). In this particular constellation of the academy's choice to refuse and erase Indigenous knowledge, the white European researcher was the one to produce the theoretical framing for a sociocultural context in Mozambique that she was unfamiliar with, while the Mozambican researcher delivered the data to be framed in a particular way. Although the process itself was less clear-cut (e.g. data interpretation was shared), this general dynamic overlegitimized European epistemologies and designated author collaboration as a relationship that works for and under the auspices of the imperial archive.

Today, Hanna would be inclined to understand the question from her colleague as a comment on the absence of criticality as strong anti-colonial theory in her paper, and see that the underlying issue was not merely one of framing a study. As Cusicanqui (2019) explains, "There can be no discourse of decolonization, no theory of decolonization, without a decolonizing practice" (112). Hanna's response to her colleague would thus include an admission that she didn't frame the paper more firmly in anti-colonial theory because it was not contextualized in decolonizing practice. Instead, the writing process was driven by the perceived need to feed the empire's hunger for archivable knowledge, and also by the goal of collaborating with deeply valued colleagues.

\section{Dis-orienting from imperial straightening devices and myths of choice}

What does it mean to be oriented? How is it that we come to find our way in a world that acquires new shapes, depending on which way we turn? If we know where we are, when we turn this way or that, then we are oriented. We have our bearings. We know what to do to get to this place or to that. To be oriented is also to be oriented toward certain objects, those that help us find our way. These are the objects we recognize, such that when we face them, we know which way we are facing. They gather on the ground and also create a ground on which we can gather. 
Yet objects gather quite differently, creating different grounds. What difference does it make what we are oriented toward? (Ahmed, 2006: 543)

These are the opening lines of "Orientations: Towards a Queer Phenomonology," in which Sara Ahmed offers the idea of straightening devices as ways through which things that are not in line are corrected. The purpose of these straightening devices - as in the case of confirming and growing the knowledge held by the imperial archive - is to "keep things in line, in part by holding things in place [making things that are out of line] disappear through such alignments, so when things come out of line with each other the effect is "wonky"' (562). This wonkiness (to not function correctly) is responded to with corrections in order to bring things back into alignment with the determined norms. Archivists and authors of the imperial archive (which is to say, all of us who operate in relation to the academy, regardless of our animosities, disdains, and active insurrections against it) are groomed and positioned by the imperial academy and its colonial arms to respond to these wonky productions - constructing them as undesirable (to the academy), illegitimate (to the academy), even dangerous (to the people in the holds of empire). Of course, wonky knowledges may very well be dangerous (to the academy and to the empire), in that they offer possibilities for fissuring empire's myths and thus its persistent holds.

In considering the straightening devices of these vignettes, we are reminded of Ahmed's original characterisation that derives from thinking about orientation. Ahmed describes objects that have been put on display as measures of the gifts of social standing, "[making] visible a fantasy of a good life" (559). When we consider the objects of empire to include productions of knowledge logged by the imperial archive, we see academic knowledge production as displays that make visible a fantasy of the empire and its grips as legitimate.

What then is the point of questioning the notion of choice in scholarship production? We do not suggest that there is no agency, no willing or coerced desire for the social wages (DuBois, 1933/2014) of legitimacy in the eyes of the empire and its colonial powers, which are paid out for contributing to and re-inscribing the archives' shelves. What we suggest instead is the reconceptualization of the choices of scholarship formation and its knowledge production. From the standpoint of researcher choices, these vignettes consider the choices of epistemological paradigm, of methodology and methods, of ethics in relationship with those impacted by and shaping scholarship and its products, and of reflexivity oriented towards what and whom. From an understanding of imperial straightening devices, however, they offer us both greater agency and deeper implications: agency concerning our moves within, outside of, despite, and against the imperial archive, and implications to our will to make visible our fraught commitments, contingent desires, and capacities to engage in the otherwise (Gordon, 2008). They urge us to dis-orient (Merleau-Ponty, 2002) from imperial alignments and towards orientations of refusal (Mungwini, Creller, Monahan, \& Murdock, 2019; Simpson, 2007; Tuck \& Yang, 2014) and resurgence (Simpson, 2017).

Do some straightening devices shift our orientation so as to make other choices more or less visible (or even recognisable as choices)? How do straightening devices limit or occlude our capacity to imagine, or remember, other choices? The ultimate myth here is not the myth of choices. Rather the myth of choices is a signifier for the myth of engaging in dismantlement or anticolonialism within the realm of academic knowledge production. In the preceding vignettes, 
we take up Rambukwella's (2019) reflection on Cusicanqui's "incisive critique of the ironic appropriation of radical scholarly thinking grounded in local political concerns by 'first world' centers of theoretical production and their subsequent reification" (126). In so doing, we grapple with the implications of Cusicanqui's (2012/2019) criticism of the colonial structure of knowledge production and the possibilities of moving against empire when also engaging in knowledge production in relation to its archive (see also our opening quote, Lin, 2015).

We close with a call for an intensified pursuit of decolonizing and humanizing practices of identifying, negotiating, and disseminating knowledge beyond academia, in rejection of and unconcerned with the legitimacy of the archive. We echo la paperson's (2017) urge to conceive of a third possibility against the persistent straightening devices of imperial fit. Whether in the form of public scholarship, local knowledge return and intergenerational transfer, or ways conceived of outside of imaginaries we are privy to, consider that a decolonizing "exists already amid the colonial, and that it takes many formations at multiple scales" (52). With this in mind, la paperson offers ten axioms of this third university (52-53) - a university of an otherwise world. We align our understanding of decolonizing work with la paperson's (2017) axioms of the third university as practices that refuse to fit into a binary of "possible" vs "impossible" and instead stubbornly assemble as hopeful and yet always problematic spaces within a colonizing enterprise, humanizing threads in an imperial web that we keep weaving (Lin, 2015).

In what follows, we have adapted these axioms to consider the ways we already always have had what we need to weave our ways out of the web of the colonial archive, even as it is woven (and we have been weaving it) (Lin, 2015). We urge ourselves and each other to acknowledge and refuse imperial straightening devices and to consider the ways that epistemic reconfiguration in critical language research is possible, in that:

1. It already exists and is always assembling

2. Its mission is decolonizing in all its scalar forms

3. It is strategic and possible

4. It is always on time, but it will not always be useful

5. It is a calling and it is work

6. It is not free from its toxic relationship with empire and empire's colonizing efforts, so it is not a romance and not worth dreaming about as a romance

7. It will still be problematic

8. It is decolonizing and anticolonial but not indigenizing. It is not where you/we hope to be, become, or to return to

9. It is not about a utopia. It may still discipline and be disciplinary, because it may need to retain boundaries in order to survive against erasure and co-optations

10. What it does will rely on what we do and do not do, what we succumb to and resist, what we are able to imagine and collectively create, what we desire and what we keep safe

\section{5 (On time, being on time, and being in time)}

The process for developing the autoethnographic narrative vignettes that carried this manuscript happened in the context of the early months of the COVID-19 pandemic. We came to seeing these straightening devices at a time when aspirations for inclusion in the imperial archive were 
acutely disorienting. We wanted to write something together because we wanted to be together. We wanted to write something together because we had aspirations for inclusion into the archive. We wanted to write together because we wanted to write something that was grounded in recognition more than it was in aspirations.

We also wanted a reason to assemble and to stay connected to one another. Our relationships with each other were forged in our apprenticeships to the imperial archive and through shared experiences of struggling to find ways through its contradictory orientations. We had aims of continuing a shared sense-making that began years earlier as we were entering into this relationship with the archive, and we recognized ourselves in one another's stories over and over again. At the start of this writing, each of us confessed to being stretched thin and overcommitted, while simultaneously missing each other. A relationship of missing, as we've discussed in this piece, is a construct of academia itself - and while desiring to read, write, and think together are human practices, these desires have been co-opted by the legitimizing arrangements of the academy. Thus, with this desire "other things follow(ed), given how the social (was) already arranged" (Ahmed, 2006: 563). We were bending to the desire to be together and just be, but we straightened ourselves to the need to have a product to show for it.

Constituent to the myths of academia is the production of knowledge, and, as with any intimacies of empire, the processes of production are hidden, held secret, and made public in re- narrated and sanitized forms. What were the realities of this particular production of knowledge that we kept intimate, and have attempted to straighten out of existence to legitimize the academic integrity of this production? Ten requests for extensions, eleven missed deadlines, childbirth, mothering of children, mothering of children through a global pandemic and its closures, state violence where we live, contentious labor union negotiations and a faculty strike, being children of aging parents with no access to vaccines against COVID-19, aging parents across oceans, aging parents across countries, depressions, anxieties, physical pains, illnesses, losses, mourning, and increasing messaging to carry on.

Among the myths of academia are myths of scarcity: Ontological knowledge is scarce, and must be found, extracted, and claimed. Knowledge is a spectrum that will someday be completed. Its remaining gaps are scarce and must be found, filled, and laid claim to. Authority and validity in knowing is scarce and must be claimed, proven, and territorialized. Time is scarce and must be spent wisely, on things that will prove we are necessary in the economy of colonialism and maintaining its archive. In our writing, we found ourselves being straightened and straightening to the devices of time: that there isn't enough of it, that it's possible to use it wisely and to waste it, and that what determines wisdom and waste based on what commodities your thoughts and relations can produce and what you can then make of them.

These narratives of scarcity straighten us away from desires that are multiple and multiplying, unnecessary, unexplainable, and refusing to be normed. To refuse to straighten and be straightened is to refuse to comply with time as teleology and time as slowly and steadily filling up. Instead, we seek time that curves and curves back, spirals and opens to complexity. Time that it is impossible to "be behind" within, but instead carries a winding and tangling path. We close this with our own questions of possibility for epistemic refusal and reclamation. We close by 
asking what it might be to reject time in its many straightenings, and to instead live and seek to understand in what we are able to collectively create, what we desire, and what we keep safe.

\section{References}

Accomplices not allies: Abolishing the ally industrial complex. On nonprofit-certified "white allies" and privilege theory. (2015). Revolutionary solidarity: A critical reader for accomplices, (pp. 35-43). [zine]. n.p.

Ahmed, S. (2006). Orientations: Toward a queer phenomenology. GLQ: A journal of Lesbian and Gay Studies, 12(4), 543-574.

Ahmed, S. (2007a). Multiculturalism and the promise of happiness. New formations, 63(1), 121137.

Ahmed, S. (2007b). A phenomenology of whiteness. Feminist theory, 8(2), 149-168.

Burns, K. (2010). Into the archive: Writing and power in colonial Peru. Duke University Press.

Castro-Gómez, S. (2007). The missing chapter of empire: Postmodern reorganization of coloniality and post-Fordist capitalism. Cultural studies, 21(2-3), 428-448. Chang, H., Ngunjiri, F., \& Hernandez, K. A. C. (2016). Collaborative autoethnography. Routledge.

Cushing-Leubner, J. (2020a). Discourse and whiteness. In Z. Casey (Ed.), Encyclopedia of critical whiteness studies in education, pp. 133-143. Boston: Brill Sense.

Cushing-Leubner, J. (2020b). Heritage language education: A holistic view. In S. Laviosa \& M. González Davies (Eds.), The Routledge Handbook of Translation and Education, pp. 303-321 London: Routledge.

Cusicanqui, S.R. (2012). Ch'ixinakax utxiwa: A reflection on the practices and discourses of decolonization. The South Atlantic Quarterly, 111(1), 95-109.

Cusicanqui, S. R. (2019). Ch'ixinakax utxiwa: A reflection on the practices and discourses of decolonization. Language, Culture and Society, 1(1), 106-119.

Deleuze, G., \& Guattari, F. (1988). A thousand plateaus: Capitalism and schizophrenia. Bloomsbury Publishing.

Du Bois, W. E. B. (1933/2014). Black Reconstruction in America. Oxford University Press.

Garbisch, A. J. (2021). Constructing identity by writing roots into life: a poetic-narrative autoethnography. Journal of Poetry Therapy, 34(1), 37-47.

Gopinath, G. (2018). Unruly visions: The aesthetic practices of queer diaspora. Duke University Press. 
Gordon, A. F. (2008). Ghostly matters: Haunting and the sociological imagination. University of Minnesota Press.

Gramsci, A. (1999). Selections from the prison notebooks of Antonio Gramsci (Q. Hoare and G. Nowell Smith, trans.). London: The Electric Book Company, Ltd.

Hanauer, D. I. (2012). Growing up in the unseen shadow of the Kindertransport. Qualitative Inquiry, 18(10), 845-851.

Heller, M., \& McElhinny, B. (2017). Language, capitalism, colonialism: Toward a critical history. University of Toronto Press.

la paperson. (2017). A third university is possible. University of Minnesota Press.

Lin, A. (2015). Preface: Can a spider weave its way out of the web that it is being woven into, just as it weaves? In H. Zhang, P.W.K. Chan, \& K. Kenway (Eds.), Asia as method in education studies: A defiant research imagination (xxi-xv). London: Routledge.

Linkon, S., \& Mullen, B. (1995). Gender, race, and place: Teaching working-class students in Youngstown. The Radical Teacher, 46, 27-32.

Lorente, B. P. (2019). Dismantling the colonial structure of knowledge production. Language, culture and society, 1(1), 152-156.

Lowe, L. (2007). The worldliness of intimacy. In D. Ganguly, \& N. Curthoys. Edward Said: The legacy of a public intellectual (pp. 121-151). Academic Monographs.

Lowe, L. (2015). The intimacies of four continents. Duke University Press.

Merleau-Ponty, M. (2002). The phenomenology of perception (trans. Colin Smith). London: Routledge.

Mignolo, W. D. (2009). Epistemic disobedience, independent thought and decolonial freedom. Theory, Culture \& Society, 26(7-8), 159-181.

Moustakas, C. (1994). Phenomenological research: Analyses and examples. Phenomenological Research Methods, 120-154.

Mungwini, P., Creller, A., Monahan, M. J., \& Murdock, E. G. (2019). Why epistemic decolonization?. Journal of World Philosophies, 4(2), 70-105.

Myers, K. (2014, November). The intimacy of three settler nations: Colonialism, race, and child welfare. Gazillion Voices.

Nagar, R. (2014). Muddying the waters: Coauthoring feminisms across scholarship and activism. University of Illinois Press 
O’Brien, J. M. (2010). Firsting and lasting: Writing Indians out of existence in New England. University of Minnesota Press.

Pieratos, N. A., Manning, S. S., \& Tilsen, N. (2021). Land Back: A meta narrative to help indigenous people show up as movement leaders. Leadership, 17(1), 47-61.

Rådesjö, M. (2018). Learning and growing from 'communities of practice': autoethnographic narrative vignettes of an aspiring educational researcher's experience. Reflective Practice, 19(1), 68-80.

Rambukwella, H. (2019). On hybridity, the politics of knowledge production and critical language studies. Language, Culture and Society, 1(1), 126-131.

Richards, T. (1993). The imperial archive: knowledge and the fantasy of empire. Verso.

Rosiek, J. L., Snyder, J., \& Pratt, S. L. (2020). The new materialisms and Indigenous theories of non-human agency: Making the case for respectful anti-colonial engagement. Qualitative Inquiry, 26(3-4), 331-346.

Russell, M. (2019). Capitalism and disability: Selected writings by Marta Russell. Haymarket Books.

Said, E. W. (2012). Culture and imperialism. Vintage.

Saldaña, J. (2021). Gay-Tex-Mex: Autoethnographic Vignettes. Cultural Studies $\leftrightarrow$ Critical Methodologies, 21(2), 143-145.

Siefert, B., Salas, S., \& D’Amico, M. M. (2018). Problematizing deficit representations of inservice teachers. TESOL Journal, 9(2), 397-400.

Silko, L. M. (2006). Ceremony. Penguin.

Simpson, A. (2007). On ethnographic refusal: Indigeneity, "voice," and colonial citizenship. Junctures, 9, 67-80.

Simpson, L. B. (2017). As we have always done: Indigenous freedom through radical resistance. University of Minnesota Press.

Smith, L. T. (2015). Decolonizing knowledge: Toward a critical indigenous Research Justice praxis. Research justice: Methodologies for social change, 205-210.

Stoler, A. L. (2002). Colonial archives and the arts of governance. Archival science, 2(1-2), 87109. 
TallBear, K. (2017). Beyond the life/not-life binary: A feminist-indigenous reading of cryopreservation, interspecies thinking, and the new materialisms. In J. Radin \& E. Kowal (Eds.), Cryopolitics: Frozen life in a melting world, 179-202. MIT Press.

Tuck, E. (2011). Rematriating curriculum studies. Journal of Curriculum and Pedagogy, 8(1), 34-37.

Tuck, E., \& Yang, K. W. (2014). R-words: Refusing research. In D. Paris \& M. Winn (Eds.), Humanizing research: Decolonizing qualitative inquiry with youth and communities (pp. 223247). Sage Publications.

Tuck, E., \& Yang, K. W. (Eds.). (2018). Toward what justice?: Describing diverse dreams of justice in education. Routledge.

Verene, D. P. (1991). The new art of autobiography: An essay on the Life of Giambattista Vico, written by himself. Oxford University Press on Demand.

Virtanen, T., Silander, C., Pietilä, M. (2014). National steering and profiling of academic research in Finland and Sweden. In T. Aarrevaara \& E. Berg (Eds.), Higher Education and Research in Academe: Who should pay? (pp. 29-40). Luleå tekniska universitet.

Wa Thiong'o, N. (1992). Decolonising the mind: The politics of language in African literature. East African Publishers.

Wolfe, P. (2006). Settler colonialism and the elimination of the Native. Journal of genocide research, 8(4), 387-409.

'Sincere thanks to reviewers of earlier versions of this manuscript for pointing this out.

' Sincere thanks to reviewers of earlier versions of this manuscript for pointing this out. 